\title{
The Effect of Motivation, Work Environment, and Infrastructure on Teacher Performance in SMK Negeri 1 Kutacane
}

\author{
Arief Rachman Hakim ${ }^{1}$, Yeni Absah ${ }^{2}$, Linda Trimurni Maas ${ }^{2}$ \\ ${ }^{1,2}$ Master of Management Study Program on Postgraduate School of University of Sumatera Utara \\ Corresponding Author: Arief Rachman Hakim
}

DOI: https://doi.org/10.52403/ijrr.20220232

\begin{abstract}
This study aims to determine the effect of motivation, work environment, and infrastructure on teacher performance simultaneously or partially. The research also aims to obtain an effective policy formulation as an improvement/improvement of teacher performance at SMK Negeri 1 Kutacane. The sample in this study amounted to 82 teachers. This type of research is descriptive quantitative. Data was collected by distributing questionnaires directly to teachers and secondary data. The data analysis technique used is the instrument test, namely the validity test and the reliability test as well as the analytical method consisting of the t test, $\mathrm{f}$ test, and data analysis using multiple linear regression models. The results of the study indicate that motivation, work environment, and infrastructure significantly positively affect teacher performance simultaneously. Partially, motivation and environment significantly affect teacher performance, while infrastructure partially has no significant effect on teacher performance. These results show that if the motivation, work environment, and infrastructure are improved together, it will further improve the performance of teachers at SMK Negeri 1 Kutacane.
\end{abstract}

Keywords: Motivation, Work Environment, Infrastructure, and Teacher Performance.

\section{BACKGROUND}

Performance is the result of work or achievements achieved by a person, which is assessed based on the quality and quantity, by the tasks given to achieve common goals (Adam, 2014). In the Law on Teachers and Lecturers of the Year Number 14 of 2005 article 1 paragraph (1), teachers are professional educators with the main task of educating, teaching, guiding, directing, training, assessing and evaluating students in early childhood education through formal education, primary education, and secondary education.

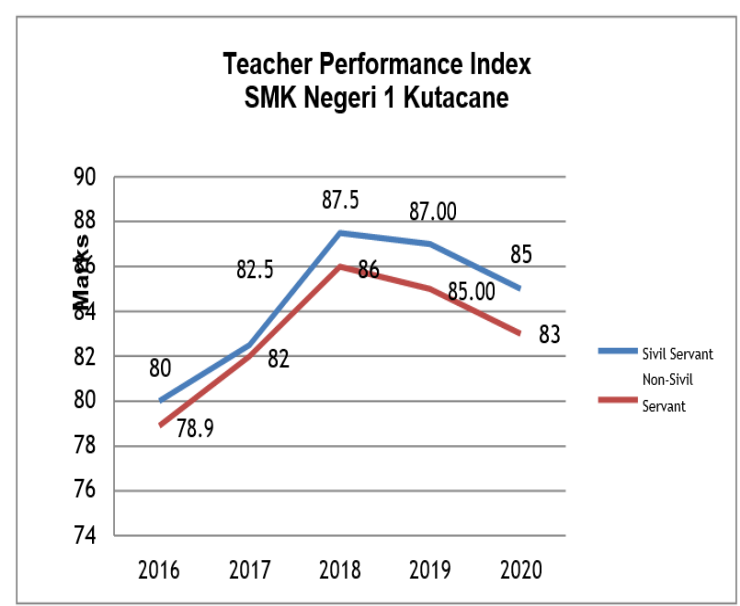

Figure 1. Performance Index of Educators at SMK N 1 Kutacane Period 2016-2020

Teacher performance is a performance or performance carried out by teachers in carrying out their duties as educators, and the quality of teachers will greatly determine the quality of educational outcomes because teachers are the parties who most often interact directly with students in the learning process at school 
educational institutions. The success of students in the teaching and learning process in the school environment is influenced by the performance of good teachers so that they can create quality human resources through education. Factors that affect teacher performance can come from within the individual itself, such as motivation, skills, and education.

Based on the data above, it was found that there were problems at SMK Negeri 1 Kutacane which could be seen within a period of 5 years the performance of educators at SMK Negeri 1 Kutacane had increased from 2016 to 2018 and decreased from 2019 to 2020.

At SMK Negeri 1 Kutacane the principal demands that teachers be more able to conduct research in teaching and learning activities, develop themselves, make articles, and make scientific works as one of the implementations in teacher performance. However, the teachers at SMK Negeri 1 Kutacane still have difficulties in developing themselves. This is due, among others, to the teachers at SMK N 1 Kutacane, the lack of a relationship between the principal and the teacher, and the lack of motivation given by the principal to the teacher.

Furthermore, an unfavourable work environment can result in more manpower and working time and does not support obtaining an efficient work system design. Nitisemito (2015), defines the work environment as follows: the work environment is everything that is around the workers that can affect them in carrying out the tasks assigned.

The work environment at SMK Negeri 1 Kutacane there are still some problems related to the lighting or light in the school is not good because the light bulbs in the classroom are still not enough then the air circulation is still not good this is due to the lack of air ventilation in the classroom and teacher's room, noise in the school due to the location of the school being right across the highway. For the learning process to be carried out effectively and efficiently, schools need to provide adequate learning infrastructure.

Another related factor is motivation. The teaching and learning process is a process that contains a series of actions of teachers and students based on reciprocal relationships that take place in educational situations to achieve certain goals.

The results of Heriati and Daulay's research (2020) partially state that the work environment variable has a positive and significant effect on teacher performance, the work facilities variable has a positive and significant effect on teacher performance and the motivation variable has a positive and significant effect on teacher performance. Simultaneously, the variables of work environment, work facilities and motivation have a positive and significant effect on teacher performance. Variables of Work Environment, Work Facilities and Motivation have a positive and significant impact on teacher performance at the Azadin Anhar Education Foundation, Wampu District, Langkat Regency.

Febri Andriana's (2020) research show that Discipline, Work Environment, Motivation affect the performance of Teachers of SMK Negeri 1 Alian Kebumen and Sahlan Lubis (2020) shows that the results of the $\mathrm{F}$ (simultaneous) test show that the work environment, work discipline, and work motivation have a significant and positive influence on teacher performance. This means that if the Work Environment, Work Discipline, and Work Motivation are jointly improved, the teacher's performance will also increase significantly.

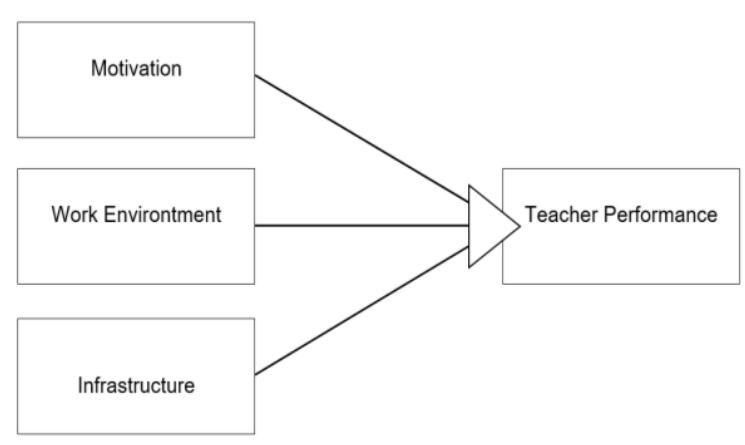

Figure 2. Conceptual Framework 


\section{Hypotheses}

H1: Motivation has a significant effect on teacher performance at SMK Negeri 1 Kutacane.

$\mathrm{H} 2$ : Work environment has a significant effect on teacher performance at SMK Negeri 1 Kutacane.

H3: Facilities and infrastructure have a significant effect on teacher performance at SMK Negeri 1 Kutacane.

H4: Motivation, work environment, and infrastructure have a significant effect on teacher performance at SMK Negeri 1 Kutacane.

\section{RESEARCH METHOD}

This research is descriptive. The approach in this study uses quantitative as confirmed by previous research conducted by Prasetyo and Jannah (2019). This research was conducted at the school of SMK N 1 Kutacane which is located at $\mathrm{Jl}$. Louser No. 196 Gumpang Jaya, Kab. Southeast Aceh Prov. Aceh. While the time of the research starts in March 2021 until June 2021.

The population in this study were all educators and education staff of SMK Negeri 1 Kutacane which consisted of the principal, teachers, and students with a total of 1053 people. The sampling method in this study used a non-probability sampling method, namely by using the Slovin method technique with a total of 82 selected samples.

\section{RESULT AND DISCUSSION Coefficient of Determination Test $(R$ Square)}

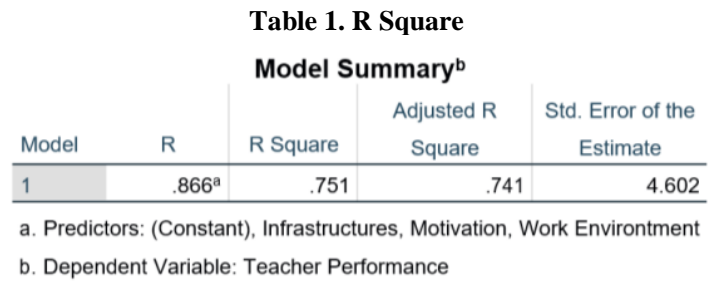

The value of the coefficient of determination ( $\mathrm{R}$ Square) is 0.751. This means that the influence of the independent variable on the dependent variable $\mathrm{Y}$ (performance) is $75.1 \%$. In other words, $75.1 \%$ of teacher performance variables can be explained by the variables of motivation, work environment, and infrastructure. The remaining $24.9 \%$ of teacher performance variables are influenced by other variables not examined. The correlation coefficient (R) of 0.866 indicates that there is a very strong relationship between the variables $\mathrm{X} 1, \mathrm{X} 2$, and $\mathrm{X} 3$.

\section{Hypotheses Test}

\begin{tabular}{|c|c|c|c|c|c|c|c|c|}
\hline \multicolumn{9}{|c|}{ Coefficients" } \\
\hline & & \multicolumn{2}{|c|}{ Unstandardized Coefficients } & \multirow{2}{*}{$\begin{array}{c}\begin{array}{c}\text { Standardized } \\
\text { Coefficients }\end{array} \\
\text { Beta } \\
\end{array}$} & \multirow[b]{2}{*}{$\mathrm{t}$} & \multirow[b]{2}{*}{ Sig. } & \multicolumn{2}{|c|}{$\begin{array}{c}\text { Collinearity } \\
\text { Statistics } \\
\end{array}$} \\
\hline \multicolumn{2}{|c|}{ Model } & B & Std. Error & & & & Tolerance & VIF \\
\hline \multirow[t]{4}{*}{1} & (Constant) & 11.148 & 3.521 & & 3.166 & .002 & & \\
\hline & Motivation & .283 & .123 & .232 & 2.307 & .024 & .317 & 3.153 \\
\hline & Work Environtment & .674 & .134 & .575 & 5.027 & .000 & .244 & 4.092 \\
\hline & Infrastructures & .124 & .113 & .108 & 1.095 & .277 & .328 & 3.051 \\
\hline
\end{tabular}

1. The effect of motivation on teacher performance is obtained $\mathrm{T}_{\text {count }}$ motivation is 2.307 and $\mathrm{T}_{\text {table }} 1.990$, thus $\mathrm{T}_{\text {count }}>\mathrm{T}_{\text {table }}(2.307>1.990)$, and $\mathrm{a}$ significant value of 0.024 , which is $<0.05$. It means that motivation partially has a positive and significant effect on teacher performance, so $\mathrm{H}_{\mathrm{o}}$ is rejected and $\mathrm{H}_{\mathrm{a}}$ is accepted. The hypothesis reads "motivation has a significant effect on teacher performance".

2. The effect of the work environment on teacher performance obtained $t_{\text {count }}$ work environment of 5.027 and $\mathrm{T}_{\text {table }} 1.990$ thus $\mathrm{T}_{\text {count }}>\mathrm{T}_{\text {table }}(5.027>1.990)$ and a significant value of 0.000 that is $<0.05$. 
It means that motivation partially has a positive and significant effect on teacher performance, so $\mathrm{H}_{\mathrm{o}}$ is rejected and $\mathrm{H}_{\mathrm{a}}$ is accepted, the hypothesis reads "the work environment has a significant effect on teacher performance".

3. The effect of infrastructure on teacher performance is obtained by $\mathrm{T}_{\text {count }}$ of 1.095 and $\mathrm{T}_{\text {table }}$ of 1.990 , thus $\mathrm{T}_{\text {count }}<$ $\mathrm{T}_{\text {table }}(1.095<1.990)$ and a significant value of 0.227 , namely $<0.05$. This means that the infrastructure partially does not have a positive and significant effect on teacher performance, so $\mathrm{H}_{\mathrm{o}}$ is accepted and $\mathrm{H}_{\mathrm{a}}$ is rejected, meaning that it is not significant, then the hypothesis reads "Facilities and infrastructure have no significant effect on teacher performance".

Table 3. Simultaneous Significance Test (Test - F)

ANOVA ${ }^{a}$

\begin{tabular}{|l|l|r|r|r|r|r|}
\hline \multicolumn{2}{|l|}{ Model } & Sum of Squares & Df & Mean Square & \multicolumn{1}{c|}{ F } & Sig. \\
\hline \multirow{3}{*}{1} & Regression & 4969.710 & 3 & 1656.570 & 78.225 & $.000^{\mathrm{b}}$ \\
\cline { 2 - 7 } & Residual & 1651.802 & 78 & 21.177 & & \\
\cline { 2 - 7 } & Total & 6621.512 & 81 & & & \\
\hline
\end{tabular}

1. Dependent Variable: Teacher Performance

2. Predictors: (Constant), Infrastructures, Motivation, Work Environtment

The results of the $F_{\text {test }}$ in table 4.15,

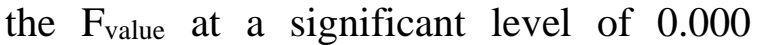
$<0.05$ and $F_{\text {count }} 78.225$ using a distribution level of $95 \%,=5 \%$, df1 $(\mathrm{k}-1)=4-1=3$, df 2 $(\mathrm{nk})=82-4=78$, then $\mathrm{F}_{\text {table }}$ is 2.72 . Then $\mathrm{F}_{\text {count }}>\mathrm{F}_{\text {table }}(78.225>2.72) \mathrm{H}_{\mathrm{o}}$ is rejected and $\mathrm{H}_{\mathrm{a}}$ is accepted, meaning that the hypothesis that reads "motivation, work environment, and infrastructure simultaneously has a significant effect on teacher performance" is accepted.

\section{The Effect of Motivation on Teacher Performance}

The results of the partial hypothesis of this study state that motivation has a positive and significant effect on teacher performance at SMK Negeri 1 Kutacane. About teacher performance, in line with Hamdana's research (2020), motivation has an important role in improving teacher performance, if a teacher is motivated, he will always have high work passion which will encourage teachers to work with good results. Providing the right and good motivation to the teacher can change the teacher's behaviour to carry out a job that has been given to him with high morale so that organizational goals can be achieved. Therefore, motivation is an absolute requirement to be considered, because it becomes a benchmark in improving teacher performance. Based on this analysis, it can be concluded that the motivational variable is an important factor and influence in improving teacher performance at SMK Negeri 1 Kutacane, Southeast Aceh Regency. This shows that the better the motivation, the higher the teacher's performance at SMK Negeri 1 Kutacane. Conversely, the less good the motivation, the lower the teacher's performance at SMK Negeri 1 Kutacane. This is in line with the research of Febri (2020), Rahmah (2020), and Sahlan (2020) which also state that the motivation variable has a positive and significant effect on teacher performance.

\section{The Influence of the Work Environment on Teacher Performance}

The results showed that there was a positive influence between the work environments on the performance of teachers at SMK Negeri 1 Kutacane with a sig. 0.002 providing a comfortable working environment for teachers is very necessary. Therefore, the work environment is very important to be considered by school management because the work environment is one of the factors that influence the 
process of activities to improve teacher performance. The work environment plays an important role in the implementation of the teacher's duties. A pleasant working environment will improve teacher performance. Therefore, the work environment is important in efforts to improve teacher performance at SMK Negeri 1 Kutacane. Based on the results of the analysis, it can be concluded that the work environment variable has a positive and significant effect so that if this variable is improved it can determine the increase in teacher performance where the influence ranks first in improving teacher performance at SMK Negeri 1 Kutacane, Southeast Aceh Regency. Therefore, the work environment needs to be improved, especially on indicators that provide a relatively low average score to be further improved to support improving teacher performance in the future. This is in line with research by Hamdana (2020), Melianah (2020) and Febri (2020) which also state that the work environment variable has a positive and significant effect on employee performance.

\section{The Effect of Infrastructure on Teacher Performance}

By the results of the regression and t-test of the infrastructure variable on teacher performance at SMK Negeri 1 Kutacane, it showed no effect and was signed with the results of tcount $0.331<$ $t_{\text {table }} 2.035$ with a significance level of 0.227 $>0.050$. This shows that the lack of available infrastructure means the lower the performance of teachers at SMK Negeri 1 Kutacane because infrastructure is a tool and equipment that is used to facilitate the learning process. On the other hand, the more adequate infrastructure facilities, the higher the performance of teachers at SMK Negeri 1 Kutacane because the adequate infrastructure available, will facilitate and facilitate the learning process. Infrastructure does not have a significant effect on the performance of teachers at SMK Negeri 1 Kutacane. This is in line with Wiji Lestari's research (2018) which also states that the infrastructure variable partially does not have a significant effect on teacher performance, therefore teachers must be able and able to operate properly the facilities provided by the school and teachers must be able to operate equipment properly. sophisticated and proficient as well as following the development of existing technology and cannot be separated from mastery of learning material so that they can provide or distribute their knowledge to students to the fullest.

\section{CONCLUSION}

1. The variables of motivation, work environment and infrastructure have a simultaneous effect on teacher performance at the State 1 Kutacane Vocational High School (SMK).

2. The motivation and work environment variables partially have a significant effect on the performance of teachers at the State 1 Kutacane Vocational High School (SMK), while the infrastructure variable has no significant effect on the teacher's performance at the State 1 Kutacane Vocational High School (SMK).

3. As much as $75.1 \%$ of teacher performance variables can be explained by the variables of motivation, work environment, and infrastructure. The remaining $24.9 \%$ of teacher performance variables are influenced by other variables not examined.

Acknowledgement: None

Conflict of Interest: None

\section{Source of Funding: None}

\section{REFERENCES}

1. A.A Gede Kresnayana Pramana, I Nyoman Sudharma. 2013. Pengaruh Kompensasi, Lingkungan Kerja Fisik dan Disiplin Kerja Terhadap Kinerja Karyawan. Fakultas Ekonomi universitas Udayana (Unud). 
Arief Rachman Hakim et.al. The effect of motivation, work environment, and infrastructure on teacher performance in SMK Negeri 1 Kutacane.

2. A.A Anwar Prabu Mangkunegara., 2015. Manajemen Sumber Daya Manusia Perusahaan, Remaja Rosdakarya, Bandung.

3. Abin Syamsuddin Makmun. (2012). Psikologi Kependidikan Perangkat Sistem Pengajaran Modul. Bandung: Remaja Rosdakarya.

4. Adlan Adam. 2014. Pengaruh Gaya Kepemimpinan Kepala Sekolah Terhadap Kinerja Guru Sekolah Dasar Negeri di Kecamatan Gondokusuman Daerah Istimewa Yogyakarta, Yogyakarta Tahun 2014. Diakses pada 3 Maret 2021 (http://eprints.uny.ac.id/14246/1/TESIS.pdf)

5. Afandi, P. (2018). Manajemen Sumber Daya Manusia (Teori, Konsep dan Indikator). Riau: Zanafa Publishing.

6. Anggrainy, Fitria Fitiani. 2020. Pengaru Sarana Prasarana dan Lingkungan Kerja Terhadap Kinerja Guru SMP Negeri di Kecamatan Sekayu. Journal Of Education Research, Vol.1 No. 2 halaman 154-159.

7. Ambarita, Biner dan Nasrun. (2016). Manajemen Pendidikan dan Peningkatan Mutu. Bandung: Alfabeta.

8. Amirono dan Daryanto, (2016), Evaluasi dan Penilaian Pembelajaran Kurikulum 2013, Yogyakarta: Gava Media.

9. Amirin M. Tatang. (Mei 2011). Manajemen Pendidikan. Yogyakarta. UNY Press. Ananda, Rusydi dan Oda Kinata Banurea, Manajemen Sarana dan Prasarana Pendidikan, Medan: Widya Puspita, 2017.

10. Alex, Nitisemito., (2015), Manajemen Sumber Daya Manusia, Pustaka setia, Bandung.

11. Arianto, D.A.N. 2013. Pengaruh Kedisiplinan, Lingkungan Kerja Dan Budaya Kerja Terhadap Kinerja Tenaga Pengajar. Jurnal Economia, Volume 9, Nomor 2, Oktober 2013, Hal:191-200.

12. Asf, Jasmani \& Syaiful Mustofa. 2013. Supervisi Pendidikan: Terobosan Baru dalam Peningkatan Kinerja Pe ngawas Sekolah dan Guru. Jokjakarta: Ar- Ruzz Media.

13. Barnawi dan Mohammad Arifin. 2014. Kinerja Guru Profesional: Instrumen Pembinaan, Peningkatan dan Penilaian. Jogjakarta: AR-RUZZ MEDIA.

14. Daryanto. (2015). Pengelolaan Budaya Dan Iklim Sekolah. Gava Media: Yogjakarta.

15. Departemen Pendidikan Nasional, 2003. Undang-Undang Nomor 20 Tahun 2003,
Tentang Sistem Pendidikan Nasional, Jakarta: Depdiknas.

16. Departemen Pendidikan Nasional, 2005. Undang-Undang Nomor 14 Tahun 2005, Tentang Guru dan Dosen, Jakarta: Depdiknas.

17. Depdiknas. 2008. Peraturan Pemerintah RI No.19 Tahun 2005 tentang Standar Nasional Pendidikan. Jakarta: Depdiknas.

18. Edy, Sutrisno, (2016), Manajemen Sumber Daya Manusia, Kencana Prenada Media Group, Jakarta. Ghozali, Imam. 2018. Aplikasi Analisis Multivariate dengan Program IBM SPSS 25. Semarang: Badan Penerbit Universitas Diponegoro

19. Hasina, A., \& Fitri, F. A. (2019). Pengaruh Beban Kerja, Motivasi, dan Integritas Terhadap Kualitas Audit. 4(4), 694-703.

20. Hamzah B. Uno, (2017) Teori Motivasi dan Pengukurannya (Analisis di bidang pendidikan). Jakarta: Bumi Aksara.

21. Hamdana. 2020. Pengaruh Gaya Kepemimpinan, Lingkungan Kerja, dan Motivasi kerja Terhadap Kinerja Guru SMP Negeri 1 Mattiro Bulu Kabupaten Pinrang. Journal Of Management Science Vol 1 No 22 halaman 281-300.

22. Hasibuan, Malayu S.P. 2010. Manajemen Sumber Daya Manusia. Jakarta: PT Bumi Aksara.

23. H.A.S Moenir. 2014. Manajemen Pelayanan Umum Di Indonesia. Jakarta: Bumi Aksara.

24. Heriati, Putri. 2020. Pengaruh Lingkungan Kerja, Fasilitas Kerja, dan Motivasi terhadap Kinerja Guru di Yayasan Pendidikan Azadin Anhar Kecamatan Wampu Kabupaten Langkat. Manajemen Bisnis Jurnal Magister Manajemen Vol. 2 No.2 halaman 182-188.

25. Kasmir. 2016. Manajemen Sumber Daya Manusia (Teori dan Praktik). Depok: PT Rajagrafindo Persada.

26. Melianah, Nurahyani Missriani. 2020. Pengaruh Lingkungan Kerja dan Motivasi Kerja Guru Sekolah Menengah Pertama di Kecamatan Prabumulih Utara. Jurnal Pendidikan Tambusai. Vol. 4 No. 3 halaman 1950-1964.

27. Nanik Legiwati. (2016). Pengaruh Pemanfaatan Sarana Dan Prasarana Pembelajaran Dan Motivasi Belajar Terhadap Hasil Belajar Siswa Kelas VII SMPN 3 Grati Satap Kabupaten Pasuruan. 
Arief Rachman Hakim et.al. The effect of motivation, work environment, and infrastructure on teacher performance in SMK Negeri 1 Kutacane.

Jurnal Penelitian Dan Pendidikan IPS (JPPI) Volume 10 No 2. 294-309.

28. Nitisemito. 2015. Manajemen Sumber Daya Manusia.Bandung: Pustaka Setia UndangUndang Nomor 14 Tahun 2005 tentang Guru dan Dosen. Jakarta, PT Media Pustaka Mandiri.

29. Sahlan. 2020. Pengaruh Lingkungan Kerja, Disiplin Kerja, dan Motivasi Kerja terhadap Kinerja Guru Madrasah Aliyah Negeri 2 Model Medan. Jurnal EduTech Vol. 6 No. 1 halaman 17- 25.

30. Sedarmayanti. 2011. Manajemen Sumber Daya Manusia. Reformasi Birokrasi dan Manajemen Pegawai Negeri Sipil, Cetakan Kelima, PT Refika Aditama, Bandung.

31. Simamora, Henry (2015). Manajemen Sumber Daya Manusia. Yogyakarta: STIEY.

32. Simanjuntak, Roby. (2015). "Analisis pengaruh lingkungan kerja, supervise pengajar dan kelengkapan sarana prasarana terhadap profesionalisme guru di sekolah menengah kejuruan". Media Mahardika Vol. 13 No 3 Mei, 2015.
33. Sinulingga, Sukaria. 2018. Metode Penelitian. Medan: USU Press.

34. Siyoto, Sandu dan Sidik, A. 2015. Dasar Metodologi Penelitian. Yogyakarta: Literasi Media Publishing.

35. Sugiyono. 2017. Metode Penelitian Kuantitatif, Kualitatif, dan R\&D. Bandung: Alfabeta, CV

36. Wahjosumidjo. 2011. Kepemimpinan Kepala Sekolah. PT. RajaGrafindo Persada, Jakarta.

37. Ilyas, Yaslis. 2012. Kinerja, teori, penilaian dan penelitian. Jakarta: Pusat Kajian Ekonomi Kesehatan FKM Universitas Indonesia.

How to cite this article: Arief Rachman Hakim, Yeni Absah, Linda Trimurni Maas. The effect of motivation, work environment, and infrastructure on teacher performance in SMK Negeri 1 Kutacane. International Journal of Research and Review. 2022; 9(2): 229-235. DOI: https://doi.org/10.52403/ijrr.20220232 